\title{
THINGS THAT MUST BE AVOIDED IN SUBMITTING PATENT RIGHTS
}

\author{
Tio Fernandes \\ 155100075 \\ Fakultas Komputer, 448757215 \\ Mahasiswa@institusi.ac.id
}

\begin{abstract}
Patent is a special right granted by the State to the inventor of the results of his invention in the field of technology, for a certain period of time implementing the invention himself or giving his approval to others to implement it (Article 1 paragraph 1 of the Law on Patents).

What must be avoided before a Patent request is submitted is disclosure or publicly published results of research or inventions in a period of more than 6 (six) months before the patent application is submitted. Disclosure of a discovery and or research results can occur in 3 (three) ways, namely; Through technical decomposition with writing published, through product decomposition and / or how to use it in public, through product exhibitions, it can be an international exhibition in Indonesia or abroad that is official or recognized as official or in the form of an official national exhibition in Indonesia or recognized as official.

There are 2 types of patent registration systems in the context of legal protection, namely; The First to File system is a system that provides patents for those who register first for new inventions in accordance with the requirements. The First to Invent system is a system that provides patents for those who find the first innovation in accordance with predetermined requirements.
\end{abstract}

\section{Keywords: Cash Receipts and Expenditures.}

\section{A. INTRODUCTION}

The patent holder is the inventor as the patent owner or the party who receives the right from the patent owner or other party who further receives the right, which is registered in the General Register of Patents
What must be avoided before a Patent request is submitted is disclosure or publicly published results of research or inventions in a period of more than 6 (six) months before the patent application is submitted. Disclosure of a discovery and 


\section{QUIZ Selected Section Class}

or research results can occur in 3 (three) ways, namely; Through technical decomposition with writing published, through product decomposition and / or how to use it in public, through product exhibitions, it can be an international exhibition in Indonesia or abroad that is official or recognized as official or in the form of an official national exhibition in Indonesia or recognized as official.

There are 2 types of patent registration systems in the context of legal protection, namely; The First to File system is a system that provides patents for those who register first for new inventions in accordance with the requirements. The First to Invent system is a system that provides patents for those who find the first innovation in accordance with predetermined requirements.

. Patent Scope

In Indonesia the requirements for an invention that can be patented are

a. New or novelty; new means have never been disclosed before. The technology in the invention is not the same as the technology that has been revealed before.

To ensure that the researched technology has not been patented by other parties and is suitable for patenting, inventors before applying for registration can search patent documents, either through the internet or library.

b. Contains meaningful steps; not yet predictable by experts in their fields.

c. Can be applied in the world of industry means; bukanteori solely. The object of either process patents or product and appliance patents will be produced in large quantities and traded, and their rights can be transferred to the business world through a licensing agreement, or another.

Patent Registration System There are two (2) patent registration systems, namely:

a. The first to file system is a system that provides patents for those who register first for new inventions in accordance with the requirements.

b. The first to invent system is a system that provides patents for those who find the first time innovation according to predetermined requirements.

The documents required for registering a patent application are as follows:

a. Form filled in.

b. Specification of 3 double patent application.

c. Power of attorney, if submitted through legal counsel.

d. Statement letter to be granted a patent.

. Things to Avoid Before Filing a Patent

What must be avoided before a patent request is submitted is the disclosure or publicly 
published results of research or inventions within a period of 6 (six) months before a patent application is submitted. The application of the results of a study or discovery can occur in 3 ways:

a. Through the decomposition of techniques with published writing.

b. Through decomposition of products and / or ways of using them in public.

c. Through product exhibitions, it can be an international or national exhibition in Indonesia or abroad that is official or recognized as official.

What to do before applying for a patent

a. Searching for patent information on several websites, including:

b. Conduct analysis, and check whether there is a specific characteristic of the invention that will be submitted to obtain patent protection compared to the previous invention, which is still valid patent rights.

What laws and regulations govern patents?

- Law No. 14 of 2001 concerning Patents (UUP);

- Law No.7 of 1994 concerning Agreement Establishing the World Trade Organization (approval of the Establishment of a World Trade Organization);

- Presidential Decree No. 16 of 1997 concerning Ratification of PCT and Regulationsunder of the PCT;
- Presidential Decree No.15 of 1997 concerning Ratification of the Paris Convention for the Protection of Industrial Property;

- Government Regulation No. 34 of 1991 concerning Procedures for Requesting Patents;

- Government Regulation No.11 of 1991 concerning Form and Content of Patent Letters;

- Minister of Justice Decree No. M.O1-HC.O2.10 of 1991 concerning Simple Patents;

- Minister of Justice Decree No. M.O2-HC.O1.10 of 1991 concerning the Implementation of Patent Announcements;

- Minister of Justice Decree No. N.O4-HC.O2.10 Year $1991 \quad$ concerning Requirements, Term and Procedure for Payment of Patent Fees;

- Minister of Justice Decree No. M.O6-HC.O2.10 of 1991 concerning Implementation of Submission of Patent Requests; - Minister of Justice Decree No. M.O7-HC.O2.10 Year 1991 concerning Forms and Conditions of Request for Patent Substantive Examination;

- Minister of Justice Decree No. M.O8-HC.O2.10 of 1991 concerning Recording and Request for Copies of Patent Documents;

- Minister of Justice Decree No. M.O4-PR.O7.10 of 1996 concerning Secretariat 


\section{QUIZ Selected Section Class}

\section{B. CONCLUSION}

What must be avoided before a Patent request is submitted is disclosure or publicly published results of research or inventions in a period of more than 6 (six) months before the patent application is submitted. Disclosure of a discovery and or research results can occur in 3 (three) ways, namely; Through technical decomposition with writing published, through product decomposition and / or how to use it in public, through product exhibitions, it can be an international exhibition in Indonesia or abroad that is official or recognized as official or in the form of an official national exhibition in Indonesia or recognized as official.

There are 2 types of patent registration systems in the context of legal protection, namely; The First to File system is a system that provides patents for those who register first for new inventions in accordance with the requirements. The First to Invent system is a system that provides patents for those who find the first innovation in accordance with predetermined requirements.

In Indonesia the requirements for an invention that can be patented are

a. New or novelty; new means have never been disclosed before. The technology in the invention is not the same as the technology that has been revealed before. To ensure that the researched technology has not been patented by other parties and is suitable for patenting, inventors before applying for registration can search patent documents, either through the internet or library. b. Contains meaningful steps; not yet predictable by experts in their fields.

c. Can be applied in the world of industry means; bukanteori solely. The object of either process patents or product and appliance patents will be produced in large quantities and traded, and their rights can be transferred to the business world through a licensing agreement, or another.

Patent Registration System

There are two (2) patent registration systems, namely:

a. The first to file system is a system that provides patents for those who register first for new inventions in accordance with the requirements.

b. The first to invent system is a system that provides patents for those who find the first time innovation according to predetermined requirements.

The documents required for registering a patent application are as follows:

a. Form filled in.

b. Specification of patent application: 3 copies.

c. Power of attorney, if submitted through legal counsel. 
d. Statement letter to be granted a patent.

Things to Avoid Before Filing a Patent

What must be avoided before a patent request is submitted is the disclosure or publicly published results of research or inventions within a period of 6 (six) months before a patent application is submitted. The application of the results of a study or discovery can occur in 3 ways:

a. Through the decomposition of techniques with published writing.

b. Through decomposition of products and / or ways of using them in public.

c. Through product exhibitions, it can be an international or national exhibition in Indonesia or abroad that is official or recognized as official.

What to do before applying for a patent

a. Searching for patent information on several websites, including:

b. Conduct analysis, and check whether there is a specific characteristic of the invention that will be submitted to obtain patent protection compared to the previous invention, which is still valid patent rights.

\section{ACKNOWLEDGEMENT}

University Of Indonesia University Of Mitra Indonesia

Telkom University

University Of Mellbourne

Saitama Universit

\section{REFERENCE (Based ISO 690 )}

[1]

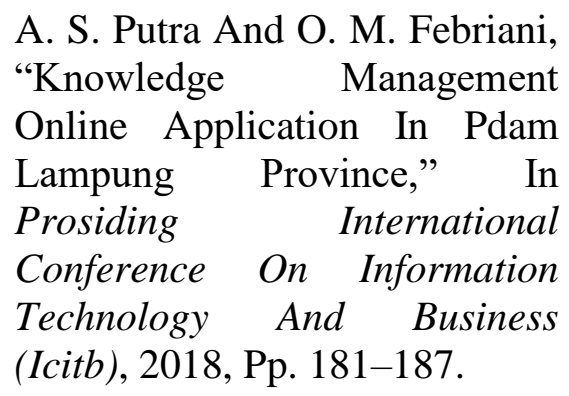

[2] A. S. Putra, O. M. Febriani, And B. Bachry, "Implementasi Genetic Fuzzy System Untuk Mengidentifikasi Hasil Curian Kendaraan Bermotor Di Polda Lampung," J. Sist. Inf. Dan Manaj. Basis Data, Vol. 1, No. 1, Pp. 21-30, 2018.

[3] O. M. Febriani And A. S. Putra, "Sistem Informasi Monitoring Inventori Barang Pada Balai Riset Standardisasi Industri Bandar Lampung," J. Inform., Vol. 13, No. 1, Pp. 90-98, 2014.

[4] Putra, Arie Setya. "2018 Artikel Struktur Data, Audit Dan Jaringan Komputer." (2018).

[5] Putra, A. S. (2018, July 17). Paperplain Fundamental Create Application With Borland Delphi 7.0 University Of Mitra Indonesia. Retrieved From Osf.Io/Pbrn9. 


\section{E. REFERENCE $($ Based APA $)$}

Putra, A. S., Aryanti, D. R., \& Hartati, I. (2018, November). Metode SAW (Simple Additive Weighting) sebagai Sistem Pendukung Keputusan Guru Berprestasi (Studi Kasus: SMK Global Surya). In Prosiding Seminar Nasional Darmajaya (Vol. 1, No. 1, pp. 85-97).

Sari, D. P., Febriani, O. M., \& Putra, A. S. (2018, November). Perancangan Sistem Informasi SDM Berprestasi pada SD Global Surya. In Prosiding Seminar Nasional Darmajaya (Vol. 1, No. 1, pp. 289-294).

Putra, A. S. (2018). Paperplain: Execution Fundamental Create Application With Borland Delphi 7.0 University Of Mitra Indonesia.

Putra, A. S., Sukri, H., \& Zuhri, K. Sistem Monitoring Realtime Jaringan Irigasi Desa (JIDES) Dengan Konsep Jaringan Sensor Nirkabel. IJEIS (Indonesian Journal of Electronics and Instrumentation Systems), 8(2), 221232.

Darmawan, A., Yuliawati, D., Marcella, O., \& Firmandala, R. (2016). Sistem Absensi dan Pelaporan Berbasis Fingerprint dan SMS Gateway. EXPLORE, 7(1).

Febriani, O. M., Wahyuni, T., \& Yusuf, S. (2017). DESIGN OF WEBSITE-BASED INFORMATION SYSTEM FOR EDOCUMENT ADMINISTRASI IN THE COMMUNITY SERVICE UNIT (A Case Study at Rajabasa District). INTERNATIONAL JOURNAL OF
COMPUTERS \& TECHNOLOGY, 16(7), 7010-7020.

Febriani, O. M., \& Wahyuni, T. (2017, October). PERANCANGAN SISTEM E-DOCUMENT ADMINISTRASI LOGBOOK PENELITIAN PADA UNIT LAYANAN DI BANDAR LAMPUNG. In Prosiding Seminar Nasional Darmajaya (Vol. 1, No. 1, pp. 187-194).

Febriani, O. M., \& Permadi, A. B. (2017). Implementasi Sistem Aplikasi Data Bimbingan dan Pelanggaran Siswa pada Sekolah Menengah Atas di Lampung Tengah dengan Metode Analisis dan Desain Sistem Terdistribusi (SSAD). EXPERT, 7(1).

Febriani, O. M., \& Ambarwati, L. (2015). PERANCANGAN APLIKASI PENGOLAHAN DATA PENJUALAN UKM KELANTING KHAS TELO DESA SIDOHARJO KECAMATAN JATI AGUNG KABUPATEN LAMPUNG SELATAN. Jurnal Teknologi Informasi dan Bisnis Pengabdian Masyarakat Darmajaya, 1(1), 77-95.

Febriani, O. M. (2015). Rancang Bangun Aplikasi Ecommercemenggunakan Freewebstore pada UKM Kelanting di Desa Sidoharjo Lampung Selatan. Prosiding Sembistek 2014, 1(02), 446-458. 